\title{
Analyzing THM Concentrations in Selected Indoor Swimming Pool Waters in the Opole Region
}

\author{
Marta Bożym ${ }^{1}$, Iwona Kłosok-Bazan², Małgorzata Wzorek ${ }^{3 *}$ \\ ${ }^{1}$ Department of Environmental Engineering, Opole University of Technology, \\ Mikołajczyka Street 5, 45-271 Opole, Poland \\ ${ }^{2}$ Department of Thermal Engineering and Industrial Facilities, Opole University of Technology, \\ Mikołajczyka Street 5, 45-271 Opole, Poland \\ ${ }^{3}$ Department of Process Engineering, Opole University of Technology, \\ Mikołajczyka Street 5, 45-271 Opole, Poland
}

Received: 10 March 2017

Accepted: 11 July 2017

\begin{abstract}
The aim of this study was to determine the level of disinfection by-products in swimming pool waters in the Opole region. The authors paid special attention to determining the concentrations of trihalomethanes (THMs), which are formed in water during disinfection.

Five indoor swimming pools were selected to provide a different range of basin capacity of pools, number of users, and treatment methods. In analyzed waters we found trihalomethane (THM) concentrations in a wide range at $27.6-278.6 \mu \mathrm{g} / \mathrm{dm}^{3}$. The detected level of total THMs in $57 \%$ of samples didn't fulfill the new proposal of requirements for swimming pool water quality $\left(100 \mu \mathrm{g} / \mathrm{dm}^{3}\right)$. The dominant compound of THMs was chloroform because of chlorine application in the disinfection method. All tested objects had to implement corrective action plans, the effect of which was to reach the limit of THM total concentration.
\end{abstract}

Keywords: swimming pool, disinfection by-products, trihalomethanes (THMs)

\section{Introduction}

Halogen derivatives of hydrocarbons, the so-called halomethanes or trihalomethanes (THMs), are formed in water treated for the purpose of disinfection - mostly when chlorine compounds are used. What is determined most frequently are compounds with chlorinated derivatives of methane (THM), which are chloroform $\mathrm{CHCl} 3$ (TCM), bromodichloromethane $\mathrm{CHBrCl} 2$ (BDCM), dibromochloromethane $\mathrm{CHBr} 2 \mathrm{Cl}$ (DBCM), and bromoform $\mathrm{CHBr} 3$ (TBM). The THM formation precursors in water are organic carbon of natural or anthropogenic origin $[1,2]$. Therefore, in the analysis of these compound formation processes, the concentration of their organic precursors in water should be taken into account. The halogen derivatives of hydrocarbons may be present in many types of chlorinated water and in swimming pool water, in which maintaining proper microbiological safety can be a basic yet challenging, task - more important than the control of disinfection by-products.

Many authors tested the concentrations of THMs in chlorinated swimming pool waters. A summary of the THM concentrations in indoor pools is presented in Table 1.

*e-mail: m.wzorek@po.opole.pl 
Table 1. Concentrations of trihalomethanes in indoor swimming pool waters.

\begin{tabular}{|c|c|c|c|c|c|c|}
\hline \multirow{2}{*}{ Country } & \multirow{2}{*}{$\begin{array}{l}\text { Disinfection } \\
\text { method }\end{array}$} & \multirow{2}{*}{$\begin{array}{l}\text { Number } \\
\text { of pools }\end{array}$} & \multicolumn{3}{|c|}{ THM concentration, $\mu \mathrm{g} / \mathrm{dm}^{3}$} & \multirow{2}{*}{ Reference } \\
\hline & & & mean & $\min$ & $\max$ & \\
\hline Canada, Quebec & chlorination & 15 & $55.2( \pm 31.6)$ & 12.9 & 215 & Dyck et al. (2011) [1] \\
\hline India, Nagpur & chlorination & 8 & n.d. & 90 & 335 & Thacker, Nitnaware (2003) [2] \\
\hline Canada, Quebec City & chlorination & 15 & $44.0( \pm 24.0)$ & 17.5 & 113.5 & $\begin{array}{l}\text { Simard et al. (2009) [3] } \\
\text { Simard et al. (2013) [4] }\end{array}$ \\
\hline Canada, Quebec & chlorination & 40 & $64.7( \pm 26.7)$ & 41.3 & 132.4 & Tardif et al. (2016) [5] \\
\hline Germany & chlorination & 2 & $25.6^{*}$ & $13.1 *$ & $47.8^{*}$ & Peng et al. (2016) [6] \\
\hline Spain, Barcelona & $\begin{array}{l}\text { chlorination } \\
\text { bromination }\end{array}$ & $\begin{array}{l}1 \\
1\end{array}$ & $\begin{array}{l}45( \pm 8.6) \\
58( \pm 4.8)\end{array}$ & $\begin{array}{l}35 \\
54\end{array}$ & $\begin{array}{l}75 \\
67\end{array}$ & Marco et al. (2015) [7] \\
\hline Spain, Barcelona & chlorination & 1 & 48.5 (mean) & 30.7 & 74.7 & Font-Ribera et al. (2016) [8] \\
\hline Spain, Barcelona & $\begin{array}{l}\text { chlorination } \\
\text { bromination }\end{array}$ & $\begin{array}{l}1 \\
1\end{array}$ & $\begin{array}{l}50 \text { (mean) } \\
63 \text { (mean) }\end{array}$ & $\begin{array}{l}28 \\
54\end{array}$ & $\begin{array}{l}84 \\
64\end{array}$ & Lourencetti et al. (2012) [9] \\
\hline Spain, Barcelona & chlorination & 1 & 49.6 & 35.2 & 75.2 & Richardson et al. (2010) [10] \\
\hline Portugal, Lisbon & chlorination & 30 & n.d. & 10.1 & 155 & Silva et al. (2012) [11] \\
\hline Italy, Modena & chlorination & 5 & 40.0 & 17.8 & 70.8 & Fantuzzi et al.(2001) [12] \\
\hline Italy, Emilia Romagna & chlorination & 24 & $36.9( \pm 28.2)$ & 6.8 & 134 & Righi et al.(2014) [13] \\
\hline United Kingdom, London & chlorination & 8 & $132.4( \pm 1.4)$ & 57 & 222.5 & Chu, Nieuwenhuijsen (2002) [14] \\
\hline Korea, Seoul & $\begin{array}{c}\text { chlorination } \\
\text { ozone/chlorination }\end{array}$ & $\begin{array}{l}72 \\
86\end{array}$ & $\begin{array}{l}32.9( \pm 2.4) \\
23.3( \pm 2.2)\end{array}$ & $\begin{array}{l}0.2 \\
0.2\end{array}$ & $\begin{array}{c}101.7 \\
64.9\end{array}$ & Lee et al. (2009) [15] \\
\hline $\begin{array}{l}\text { Thailand, Nakhon } \\
\text { Pathom Municipality }\end{array}$ & chlorination & 1 & $46.7( \pm 8.2)$ & 26.2 & 65.1 & Panyakapo et al. (2008) [16] \\
\hline
\end{tabular}

*Total THMs (the sum of TCM and DCBM); concentrations of CDBM and TBM were below LOD; n.d. - no data

It can be said that the concentrations of THMs in pool waters have wide limits, with a range of values of $0.2-335 \mu \mathrm{g} / \mathrm{dm}^{3}$. The largest spread of THM values was obtained by Thacker et al. [2] in India (90 to $\left.335 \mu \mathrm{g} / \mathrm{dm}^{3}\right)$ and by Dyck et al. [1] (12.9 to $\left.215 \mu \mathrm{g} / \mathrm{dm}^{3}\right)$ in studies performed in 15 indoor swimming pools in Canada. An average concentration of THMs in pool waters usually does not exceed the value of tens of $\mu \mathrm{g} / \mathrm{dm}^{3}$. Only Chu et al. [14] presented a higher level of THM concentrations in waters up to $132 \mu \mathrm{g} / \mathrm{dm}^{3}$ in swimming pools in London.

For this wide range of values could impact several factors that influence THM formation in water such as disinfection processes and chemicals, water sources, $\mathrm{pH}$, temperature, concentration of residual chlorine, residence time, reaction time, total or organic carbon, and disturbance [9].

THMs are volatile compounds so their accumulation in the ambient air of swimming pool halls can be noted as being significant [14]. Additionally, inhalation exposure will be largely associated with volatile substances that are lost from the water surface, but will also include some inhalation of aerosols within a pool where there is significant splashing [17]. Many authors [1, 18-21] and WHO data point out that the toxicity of those hazardous substances introduced by the inhalation route is much higher than by ingestion or through dermal contact. The International Agency for Research on Cancer (IARC) classified chloroform and bromodichloromethane as being possibly carcinogenic to humans (group 2B) [13].

For these reasons the World Health Organization (WHO) has published international guidelines for the safety of swimming pools and similar recreational water environments, including standards for minimizing microbial and disinfection by-product hazards [22-23]. WHO recommendations have been taken into account by many EU countries as national law. In Poland, for example, standards for swimming pool water quality are regulated in national law by the minister of health regarding requirements that need to be met by water in swimming pools. Acceptable THM concentrations indicated in this Regulation are $100 \mu \mathrm{g} / \mathrm{dm}^{3}$ [24].

Transport from swimming pool waters to the air will depend on a number of factors, but the most important are: THM concentrations in pool water, temperature, and the amount of splashing. Undoubtedly THM concentrations in indoor pools depend also on factors such as ventilation, the size of the building, surface disturbance, air circulation, and the disinfection method [1, 2, 14, 25]. The most important element against THM creation is strict compliance with the standards of disinfectants/ chlorine concentration in the swimming pool water. 
It may happen that the chloride concentration in swimming pool water considerably exceeds the recommended level because of the need to obtain required sanitation effects. Sometimes in swimming pools, alternative disinfection methods such as ozonization, UV radiation, electrolysis, bromination, and silver copper nanoparticles have been used [18, 26-27]. Ozone oxidation as the initial stage of water disinfection reduces the amount of chlorines used, and thus the potential of THM formation. But ozonation is not often used as one swimming pool water disinfection method due to its short-term sanitation effects [9, 15, 28]. Among other methods are bromination or electrochemical methods [15]. However, it has been proven that they form brominated derivatives, which are causing much more risk than chloroform $[9,29]$. Although the method of exposure to UV radiation should contribute to the destruction of organic compounds in water, it may cause an increase in the synthesis of THMs [30]. Silver copper nanoparticles may negatively increase environmental impact [31]. Because the type and form of disinfectant need to be chosen with respect to specific requirements and expectations, many swimming pool exploiters choose chlorine disinfectants to ensure the microbiological safety of water.

Practice varies widely around the world, as do the levels of free chlorine that are currently considered to be acceptable in order to achieve adequate disinfection while minimizing user discomfort. For example, free chlorine levels of less than $1 \mathrm{mg} / 1$ are considered acceptable in some countries, while in other countries allowable levels may be considerably higher. That is why it seems appropriate to introduce the process of THM monitoring to determine the concentrations of these compounds in the swimming pool water and allow us to improve the safety of swimming in such facilities. Under such circumstances risks from exposure to chlorination by-products in reasonably well-managed swimming pools would be considered to be small.
In the literature, there is no published data connected with monitoring THMs in Polish swimming pool waters. In 2003 Czajka et al. [32] only published the results of the brine water. For this reason, the authors decided to carry out the study on the selected indoor swimming pools to determine the THMs in waters before the new Regulation of the Minister of Health from 9 November 2015 on the requirements to be met by water in swimming pools was was put into effect.

\section{Material and Methods}

\section{Sampling}

To determine the level of THMs in indoor swimming pool waters for the study we selected five swimming pools (SP) in the Opole region. All tested swimming pools are indoor objects equipped with recirculation, water filtration systems, and automatic chlorine dosing systems. Table 2 shows selected technical and technological parameters of swimming pools. Water samples were collected during the summer season at intervals of two weeks; each object was tested five times.

All water samples were taken at approximately $30 \mathrm{~cm}$ under the water surface. Amber glass bottles (100 mL) with glass screw caps were used for the collection of the treated water. The jars were completely filled to avoid evaporation of volatile compounds. Samples were not stabilized by the addition of any reagents. Samples were stored at $<4^{\circ} \mathrm{C}$ during transport to the laboratory. Immediately after sample collection (1-2h), THMs were extracted using liquid-liquid extraction with penthane (10:1, v:v) at room temperature. Samples were manually shaken (1 min) and extracts were stored in amber glass vials at $<4^{\circ} \mathrm{C}$ until analysis and were analyzed no later than 14 days after sampling.

Table 2. Selected technical and technological parameters of studied swimming pools.

\begin{tabular}{|c|c|c|c|c|c|}
\hline Parameter & SP 1 & SP 2 & SP 3 & SP 4 & SP 5 \\
\hline Volume of the swimming pool, $\mathrm{m}^{3}$ & 310 & 450 & 2,500 & 440 & 600 \\
\hline $\begin{array}{c}\text { The incidence of total exchange of } \\
\text { water in the pool } \\
\text { (technical break) }\end{array}$ & $\begin{array}{l}1 \text { per } \\
\text { year }\end{array}$ & $\begin{array}{c}1 \text { per } \\
2 \text { years }\end{array}$ & $\begin{array}{l}2 \text { per } \\
\text { year }\end{array}$ & $\begin{array}{l}2 \text { per } \\
\text { year }\end{array}$ & $\begin{array}{l}2 \text { per } \\
\text { year }\end{array}$ \\
\hline Temperature of water, ${ }^{\circ} \mathrm{C}$ & 28 & 27 & 28 & 28.5 & 27.5 \\
\hline $\begin{array}{l}\text { Dosed substance } \\
\text { to disinfect } \\
\text { and the quantity, } \mathrm{mg} / \mathrm{L}\end{array}$ & $\begin{array}{l}\mathrm{NaClO} \\
0.1-0.3\end{array}$ & $\begin{array}{c}\mathrm{NaClO} \\
0.4\end{array}$ & $\begin{array}{l}\mathrm{NaClO} \\
0.2-0.9\end{array}$ & $\begin{array}{c}\mathrm{NaClO} \\
0.2\end{array}$ & $\begin{array}{l}\mathrm{NaClO} \\
0.2-0.5\end{array}$ \\
\hline Water treatment & $\begin{array}{l}\text { Diatomaceous } \\
\text { earth pool filter }\end{array}$ & $\begin{array}{l}\text { Diatomaceous } \\
\text { earth pool filter } \\
+ \text { UV }\end{array}$ & $\begin{array}{l}\text { Diatomaceous } \\
\text { earth pool filter }\end{array}$ & $\begin{array}{l}\text { Diatomaceous } \\
\text { earth pool filter }\end{array}$ & $\begin{array}{l}\text { Gravel, sand and } \\
\text { anthracite filter } \\
+ \text { UV }\end{array}$ \\
\hline The number of pool users per day & 45 & 300 & 500 & 67 & 450 \\
\hline
\end{tabular}

SP - swimming pool; n.d. - no data 
Table 3. The results of the analysis of THMs $\left(\mu \mathrm{g} / \mathrm{dm}^{3}\right)$ in tested swimming pool waters

\begin{tabular}{|c|c|c|c|c|c|}
\hline \multirow[t]{2}{*}{ Parameters } & \multicolumn{5}{|c|}{ Number of sampling } \\
\hline & 1 & 2 & 3 & 4 & 5 \\
\hline \multicolumn{6}{|c|}{ SP 1} \\
\hline TCM & $31.1( \pm 0.1)$ & $26.4( \pm 0.2)$ & $30.8( \pm 2.0)$ & - & $29.8( \pm 0.4)$ \\
\hline $\mathrm{BDCM}$ & $2.17( \pm 0.02)$ & $2.48( \pm 0.02)$ & $2.62( \pm 0.12)$ & - & $2.54( \pm 0.03)$ \\
\hline DBCM & $2.60( \pm 0.41)$ & $1.35( \pm 0.07)$ & $<\mathrm{LOD}$ & - & $0.91( \pm 0.17)$ \\
\hline TBM & $36.2( \pm 0.2)$ & $22.4( \pm 1.2)$ & $23.0( \pm 5.4)$ & - & $81.9( \pm 3.3)$ \\
\hline$\sum \mathrm{THM}$ & $72.1( \pm 0.7)$ & $52.7( \pm 1.5)$ & $56.4( \pm 7.5)$ & - & $115.1( \pm 3.9)$ \\
\hline \multicolumn{6}{|c|}{ SP 2} \\
\hline TCM & $26.6( \pm 1.9)$ & $32.4( \pm 0.6)$ & $40.2( \pm 0.3)$ & $83.6( \pm 0.2)$ & $33.8( \pm 1.5)$ \\
\hline $\mathrm{BDCM}$ & $3.53( \pm 0.08)$ & $3.18( \pm 0.06)$ & $2.86( \pm 0.03)$ & $9.29( \pm 0.00)$ & $2.20( \pm 0.14)$ \\
\hline DBCM & $0.28( \pm 0.06)$ & $0.46( \pm 0.04)$ & $0.23( \pm 0.00)$ & $0.79( \pm 0.14)$ & $0.26( \pm 0.15)$ \\
\hline TBM & $17.4( \pm 12.2)$ & $39.9( \pm 1.0)$ & $124.5( \pm 6.0)$ & $117.8( \pm 4.5)$ & $6.6( \pm 0.0)$ \\
\hline$\sum \mathrm{THM}$ & $47.9( \pm 14.2)$ & $76.0( \pm 1.7)$ & $167.8( \pm 6.3)$ & $211.5( \pm 4.8)$ & $42.9( \pm 1.9)$ \\
\hline \multicolumn{6}{|c|}{ SP 3} \\
\hline TCM & $47.5( \pm 2.9)$ & $48.5( \pm 0.1)$ & $69.5( \pm 12.6)$ & - & $56.5( \pm 1.8)$ \\
\hline $\mathrm{BDCM}$ & $1.13( \pm 0.09)$ & $1.18( \pm 0.00)$ & $2.45( \pm 1.8)$ & - & $1.11( \pm 0.17)$ \\
\hline DBCM & $0.30( \pm 0.06)$ & $0.53( \pm 0.05)$ & $0.56( \pm 0.00)$ & - & $0.56( \pm 0.24)$ \\
\hline TBM & $186.5( \pm 5.3)$ & $6.1( \pm 5.3)$ & $206.2( \pm 75.1)$ & - & $82.7( \pm 3.9)$ \\
\hline$\sum \mathrm{THM}$ & $235.4( \pm 8.4)$ & $56.3( \pm 5.5)$ & $278.6( \pm 89.7)$ & - & $140.9( \pm 6.1)$ \\
\hline \multicolumn{6}{|c|}{ SP 4} \\
\hline TCM & $92.6( \pm 2.5)$ & $93.6( \pm 0,7)$ & $99.6( \pm 0.9)$ & - & - \\
\hline BDCM & $1.03( \pm 0.01)$ & $1.20( \pm 0,01)$ & $1.39( \pm 0.03)$ & - & - \\
\hline DBCM & $1.11( \pm 0.06)$ & $0.34( \pm 0,01)$ & $0.13( \pm 0.01)$ & - & - \\
\hline TBM & $37.8( \pm 0.4)$ & $11.9( \pm 0.6)$ & $32.5( \pm 14.2)$ & - & - \\
\hline$\sum \mathrm{THM}$ & $132.6( \pm 3.0)$ & $107.0( \pm 0,7)$ & $133.6( \pm 0.9)$ & - & - \\
\hline \multicolumn{6}{|c|}{ SP 5} \\
\hline TCM & $26.0( \pm 2.7)$ & $28.1( \pm 1.1)$ & $31.9( \pm 1.0)$ & $147.5( \pm 0.7)$ & $208.2( \pm 0.6)$ \\
\hline $\mathrm{BDCM}$ & $1.23( \pm 0.02)$ & $1,87( \pm 0.10)$ & $2.12( \pm 0.09)$ & $5.62( \pm 0.01)$ & $8.74( \pm 0.03)$ \\
\hline DBCM & $0.40( \pm 0.00)$ & $0.25( \pm 0.04)$ & $0.31( \pm 0.01)$ & $0.75( \pm 0.02)$ & $0.87( \pm 0.02)$ \\
\hline TBM & $<$ LOD & $37.6( \pm 13.0)$ & $83.5( \pm 7.6)$ & $19.1( \pm 0.3)$ & $29.9( \pm 0.4)$ \\
\hline$\sum \mathrm{THM}$ & $27.6( \pm 2.7)$ & $67.9( \pm 14.2)$ & $117.9( \pm 8.8)$ & $173.0( \pm 1.0)$ & $247.7( \pm 1.1)$ \\
\hline
\end{tabular}

TCM - chloroform; TBM - bromoform; BDCM - bromodichloromethane; DBCM - dibromochloromethane;

LOD - limit of detection $\left(<0.1 \mu \mathrm{g} / \mathrm{dm}^{3}\right)$

\section{Standards and Reagents}

A simple standard of THM (TCM, BDCM, CDBM and TBM) - concentration of $2,000 \mathrm{mg} / \mathrm{dm}^{3}$ in methanol (Restek) was used. With individual standards a mixture of THMs and methanol (Merck, GC - grade) was performed. An intermediate standard stock solution of
THMs $20 \mu \mathrm{g} / \mathrm{dm}^{3}$ was obtained by diluting the THM standard mixture methanol and was stored at $-18^{\circ} \mathrm{C}$. Calibration standards were prepared from standard stock solution in penthane (Merck, UniSolv(R)). Sufficient linearity was obtained for all THMs with the correlation coefficients $r>0.995$. 


\section{Gas Chromatographic System and Conditions}

Separation and identification of THMs was carried out with an Agilent Technologies 7890B gas chromatograph equipped with a micro-electron capture detector $(\mu \mathrm{ECD})$ and a capillary column (Ultra Inert DB$5 \mathrm{MS}, 30 \mathrm{~m} \times 250 \mathrm{~mm} \times 0.25 \mathrm{~mm}$ ). Helium was used as a carrier gas with a flow rate of $1 \mathrm{~mL} / \mathrm{min}$, and nitrogen was used as makeup gas with a flow rate of $30 \mathrm{~mL} /$ min. The oven was held at $35^{\circ} \mathrm{C}$ for $20 \mathrm{~min}$, then was ramped at $10^{\circ} \mathrm{C} / \mathrm{min}$ to $150^{\circ} \mathrm{C}$, held for $3.5 \mathrm{~min}$. at $150^{\circ} \mathrm{C}$. The injector and detector temperatures were $200^{\circ} \mathrm{C}$ and $300^{\circ} \mathrm{C}$, respectively. The injection was operated in splitless mode.

\section{Results and Discussion}

Disinfection by-products in indoor swimming pools disinfected by chlorine and UV/chlorine were tested in selected swimming pools in the Opole region. The swimming pools represented differed basin capacity, systems of treatment, and two different methods of disinfection (Table 2). Among all tested swimming pools, SP3 had the largest volume at $2,500 \mathrm{~m}^{3}$ and the largest number of swimmers (500 users/day). Other pools had basins of 310-600 $\mathrm{m}^{3}$, with average numbers of users of 45-500 per day. What seems interesting is the relatively high numbers of swimmers in two small swimming pools - SP5 and SP2: 450 users/day in SP5 and 300 users/day in SP2. Such a high number of users involves the necessity to increase the disinfection effect in order to retain the microbiological safety of water. A dose of chlorine applied to the water in sodium hypochlorite form $(\mathrm{NaClO})$ is in the range of 0.1 to $0.5 \mathrm{mg} / \mathrm{dm}^{3}$ in the smallest pool and $0.2-0.9 \mathrm{mg} / \mathrm{dm}^{3}$ in the largest one. At this point it should be noted that in the two small swimming pools with a high number of users (SP2 and SP5) disinfection process was supported by UV radiation. UV radiation inactivates microorganisms and breaks down some pollutants (e.g., chloramines) by photo-oxidation, decreasing the oxidant demand of the purified water. UV purifies the pool water as it passes through the plant room, and neither leaves residual disinfectant in the water. UV is therefore used in conjunction with conventional chlorine-based disinfectants, but as has been mentioned earlier, decreases sodium hypochlorite demand.

One of the most important and most visible parameters of swimming pool water quality is its clarity, which involves adequate water treatment processes, including filtration supported by coagulation. Coagulants or flocculants enhance the removal of dissolved, colloidal, or suspended material by bringing it out of solution or suspension as solids (coagulation), then clumping the solids together (flocculation) to produce a floc, which is more easily trapped during filtration. The well-maintained filtration system should ensure that there are no organic materials in the water, which could be the precursors of THMs. In most analyzed objects, water was removed by means of diatomaceous earth pool filters. In SP 5 the pool clarification system was based only on gravel, sand, and anthracite filters. Table 3 illustrates the average THM concentration in waters of the five selected swimming pools in the Opole region.

Chloroform was found as a dominant compound from THMs (Fig. 1). Chloroform has been commonly observed by many authors in other swimming pools using chlorination for disinfection $[9,22,33]$. As seen in the data presented in Table 2, chloroform was found in each sample of water in the range of 26 to $208.2 \mu \mathrm{g} / \mathrm{dm}^{3}$. Maximal concentration $\left(208.2 \mu \mathrm{g} / \mathrm{dm}^{3}\right)$ was observed in pool SP5 and is probably related to the UV unit problems. A drop in the effectiveness of the UV system made it necessary to use higher doses of chlorine, which translated into increasing chloroform concentration in water. In successive samples obtained from SP5, chloroform concentration was higher compared to the previous sample. It has to be noted here that on the following day, the SP was to start its planned seasonal technical break, where UV lamps were replaced.

By comparison, the concentrations of chloroform in samples of indoor swimming pool waters in the United States was an average of $67 \mu \mathrm{g} / \mathrm{dm}^{3}$, with maximum concentration of $313 \mu \mathrm{g} / \mathrm{dm}^{3}$ [33]. According to Lourencetti at al. [9], repeated chlorination in recirculation systems of swimming pools tends to increase the proportion of more chlorinated THMs due to the lack of bromine renewal compensating for the THM volatilization losses.

Concentrations of particular THMs in the water of tested pools varied considerably. Among the THMs, the highest concentration was measured for chloroform and, surprisingly, bromoform. The results of THM analysis of all swimming pools are discussed below.

For SP 1, the concentration of THMs was in the range of 52.7 to $115.1 \mu \mathrm{g} / \mathrm{dm}^{3}$ and for this pool the highest concentration in the sum of THMs was determined for chloroform (TCM), more than $50 \%$ of all THMs (Fig. 1). The TCM concentration did not change dramatically (26.4-31.1 $\left.\mu \mathrm{g} / \mathrm{dm}^{3}\right)$, whereas the concentration of bromoform varied depending on sampling time. The highest concentration of bromoform, as much

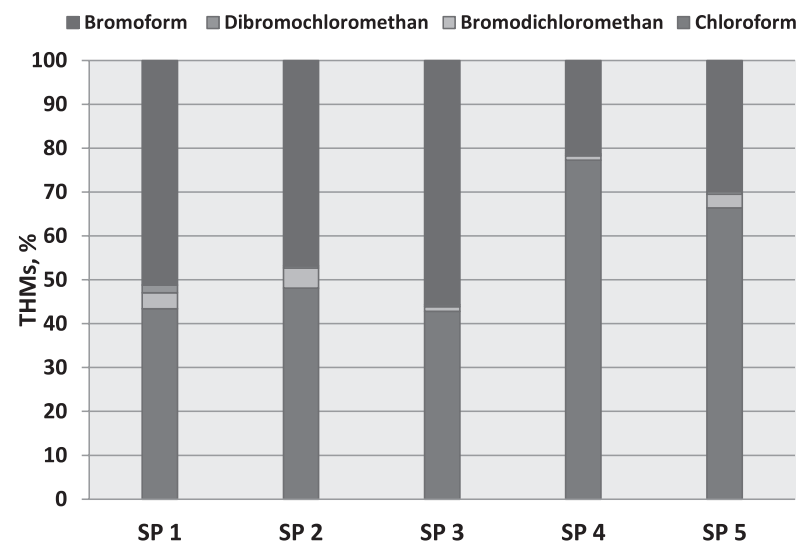

Fig. 1. The percentage of THMs in tested swimming pool waters in Opole Region. 
as $81.9 \mu \mathrm{g} / \mathrm{dm}^{3}$, was measured when the sample was collected for the fifth time, which had an impact on the high overall concentration of THMs. The lowest concentration from all THMs was measured for bromodichloromethane (BDCM) and dibromochloromethane (DBCM) in SP 1 swimming pool water.

The concentration of THMs in the SP 2 water was in the wide range of $42.9-211.5 \mu \mathrm{g} / \mathrm{dm}^{3}$. The reason for such a difference may have been a defective filtration system or water exchange in the swimming pool basin carried out after the fourth sampling. The increased concentration of bromoform (TBM) over time contributed mainly to increases in THM concentrations. The reason for such an effect was not determined. When the last sample was taken, the concentration of TBM rapidly decreased to the level of $6.6 \mu \mathrm{g} / \mathrm{dm}^{3}$. The concentration of other THMs was lower than chloroform and bromoform. Bromodichloromethane (BDCM) was in the range of 2.20 to $9.29 \mu \mathrm{g} / \mathrm{dm}^{3}$, but the highest concentration was measured for the fourth sample, i.e., when the concentration of all THMs was very high. The lowest concentration was measured for dibromochloromethane, which is confirmed by the results obtained by other authors. Its concentration was in the range of 0.23 to $0.79 \mu \mathrm{g} / \mathrm{dm}^{3}$.

The concentration of THMs in the SP 3 pool water varied greatly. The concentration of all THMs was in the range of 56.3 to $278.6 \mu \mathrm{g} / \mathrm{dm}^{3}$. The changing number of pool users and, therefore, the increase in the organic substance content in the water and in the formation of THMs may have caused the fluctuations. The high concentration of bromoform (TBM) had an impact on THMs in the SP 3 water. Therefore, there was no impact of the concentration of chloroform (TCM) on the overall concentration of THMs. The concentration of TCM was determined in a similar range of 47.5 to $69.5 \mu \mathrm{g} / \mathrm{dm}^{3}$. In SP 3 pool water the lowest concentrations of bromodichloromethane (BDCM) (1.11 to $2.45 \mu \mathrm{g} / \mathrm{dm}^{3}$ ) and dibromochloromethane (DBCM) $\left(0.30\right.$ to $\left.0.56 \mu \mathrm{g} / \mathrm{dm}^{3}\right)$ were analyzed.

For SP 4, only three samples were collected (Fig. 1) and therefore there was no effect of sampling time on the concentration of THMs in water. The lowest concentration was measured for two other THMs, i.e., bromodichloromethane (BDCM) (1.03 to $\left.1.39 \mu \mathrm{g} / \mathrm{dm}^{3}\right)$ and dibromochloromethane (DBCM) (0.13 to $1.11 \mu \mathrm{g} / \mathrm{dm}^{3}$ ).

The concentration of chloroform had a direct impact on the overall THMs in SP 5 pool water. Therefore, there was an increase in the overall concentration of THMs from $27.6 \mu \mathrm{g} / \mathrm{dm}^{3}$ in the first sample to $247.7 \mu \mathrm{g} / \mathrm{dm}^{3}$ in the fifth sample. The direct reason for such a difference may have been an inefficient sanitation system. In the case of SP 5 pool water, an ordinary sanitation system based on gravel, sand, and anthracite filters was used. In literature such filters are said to be the least efficient when it comes to removing organic particles from water. Another problem is the difficulty in cleaning the filter bed. Some authors say that in such filter beds organic matter may still react with chlorine to form THMs [34].
Therefore, in literature it is recommended to use more efficient sanitation systems, including membrane filters and reverse osmosis. The concentration of bromoform (TBM) in the SP 5 pool water varied considerably in the range of $\angle$ LOD to $83.5 \mu \mathrm{g} / \mathrm{dm}^{3}$. There was no relationship between time of sampling and the concentration of this compound in the pool water. The low concentration form of all THMs was measured for bromodichloromethane (BDCM) $\left(1.23\right.$ to $\left.8.74 \mu \mathrm{g} / \mathrm{dm}^{3}\right)$. For this compound, there was an increase in the concentration over time, similarly to the case of chloroform. The lowest concentration of THMs was observed for dibromochloromethane (DBCM) $\left(0.25\right.$ to $\left.0.87 \mu \mathrm{g} / \mathrm{dm}^{3}\right)$.

Based on the conducted research, it can be said that high variation of THMs concentration in each water sample for all sampling periods (Table 2) was obtained. This may affect the temperature of the water, number of floats, dosage of chlorine, and TOC. The sum of THMs in tested swimming pool waters is presented in Fig. 2.

Comparing the results of analyzed waters with the limit values for pool water [24], it can be noticed that many samples did not fulfil legal requirements for swimming pool water quality. (Fig. 2). Practically each pool, at least once, has exceeded the recommended value. Concentrations of THMs in SP 2, SP 3, and SP 4 exceeded the standards [24] in $40 \%$ and $100 \%$ of samples, respectively. SP 5 saw an increase of the concentration of THMs depending on the time of sampling. A properly functioning filtration and UV system will contribute positively to stop this negative effect. Therefore, the right solution would be to replace the current system of water purification in the pool with a more modern one. The introduction of obligatory pool water examinations for THM concentrations may lead to improving water sanitation systems by their replacement or upgrade which, in turn, will improve the quality of pool water and, as a result, the safety and comfort of pool users.

Water from the indoor pools can pose a health risk for swimmers. However, in indoor pools the biggest toxicological risk from THMs is the air in the hall of the swimming pools. It has been shown that THMs are absorbed mainly by inhalation rather than through the skin or accidental ingestion by swimmers [9, 13].

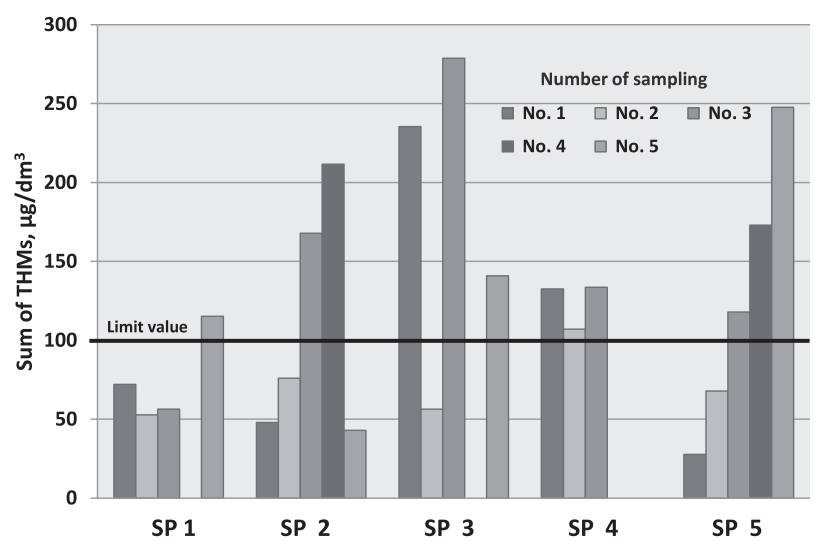

Fig. 2. The sum of THMs in tested swimming pool waters. 
But inhalation exposure will be largely associated with volatile substances that are lost from the water and will also include some inhalation of aerosols at a pool where there is significant splashing. Lee et al. [15] presented a study on health risk assessment in swimming pools and stated that the risk from oral ingestion is correlated with implemented disinfection methods. In the course of this study, there were samples from 183 indoor swimming pools collected in Seoul. It was found that THM concentrations depend on the method of disinfection. The content of THMs in chlorinated water was determined at the level of $32.9 \mu \mathrm{g} / \mathrm{dm}^{3}$, while for disinfection combining ozonation and chlorination it was only $23.3 \mu \mathrm{g} / \mathrm{dm}^{3}$, and for the electrochemically generated mixed oxidants (EGMO) method it was $58.2 \mu \mathrm{g} / \mathrm{dm}^{3}$ [15].

In many countries, despite the lack of guidelines for swimming pool water, it is assumed that THM concentration should be at the same level as the standards for drinking water $\left(100 \mu \mathrm{g} / \mathrm{dm}^{3}\right)$ in Poland [24, 35] in accordance with Directive 98/83/EC. Other European countries have already individually established the maximum value of THMs in swimming pool water, for example in Germany it is $20 \mu \mathrm{g} / \mathrm{dm}^{3}$ and in Denmark $50 \mu \mathrm{g} / \mathrm{dm}^{3}$ [36].

Because of the risk caused by THMs received orally and through skin from the pool water is negligible, swimmers are exposed to uptake of these compounds by inhalation [15]. A common solution to the issue of air pollution in swimming pool halls is prevention of THM formation by monitoring chlorinated by-products in water and properly designing the ventilation system. In order to assess the potential of creating THMs in swimming pool water, Luks-Betlej et al. [36] recommend carrying out permanent monitoring of water regarding its temperature, $\mathrm{pH}$, residual chlorine, total content of organic carbon (TOC), and the number of swimmers present.

\section{Conclusions}

There are by-products of water treatment being formed and accumulating in the waters of indoor swimming pools of the Opole region, mostly chloride derivatives of methane determined as chloroform. The identified contamination levels in each of the analyzed swimming pools exceeded the values specified in the regulation of the minister of health on requirements to be met by the swimming pool water at least once. It is significant that the tests were carried out in the summer season preceding the implementation of the said regulation and were a valuable source of information for the users of the examined facilities. All examined facilities had to implement corrective action plans, the effect of which was to reach THM total concentration of $<100 \mu \mathrm{g} / \mathrm{dm}^{3}$. The results obtained and presented in this paper do not deviate substantially from the results of studies described in multiple scientific magazines. Thus it can be stated that the maintenance of a low concentration level of water disinfection by-products is a difficult task - especially in facilities where the only water microbiological safety ensuring method is dosing chloride compounds. In facilities where the disinfection process is supported by the ozonation process or the application of UV lamps, the situation is much better. Nevertheless, in both cases the concentration of THMs must be monitored on a regular basis and the applied treatment methods require optimization in order to obtain water that is safe for all swimming pool users. Further tests are required, both in relation to quality of water as well as the air above its level since this type of THM exposure is indicated in literature as the highest threat to human health. However, it must be remembered that the source of THMs in swimming pool air is water, and the only method to reduce this threat is preventing/reducing the formation of THMs in the pool water.

\section{Acknowledgements}

The researches were supported by the Voivodship Fund for Environmental Protection and Water Management in Opole.

\section{References}

1. DYCK R., SADIQ R. RODRIGUEZ M J, SIMARD S, TARDIF R. Trihalomethane exposures in indoor swimming pools: a level III fugacity model. Water Res. 45 (16), 5084, 2011.

2. THACKER N.P., NITNAWARE V. Factors influencing formation of trihalomethanes in swimming pool water. B Environ Contam Tox. 71, 633, 2003.

3. SIMARD S. Occurrence des Sous-Produits de la Désinfection Dans L'eau des Piscines Publiques de la Ville de Québec. Occurrence of by-products of disinfection in the water of the public pools of the city of Quebec. Université Laval, Canada, 2009 [In French].

4. SIMARD S., TARDIF R., RODRIGUEZ M J. Variability of chlorination byproduct occurrence in water of indoor and outdoor swimming pools. Water Res. 47 (5), 1763, 2013.

5. TARDIF R., CATTO C., HADDAD S., SIMARD S., RODRIGUEZ M. Assessment of air and water contamination by disinfection by-products at 41 indoor swimming pools. Environ Res. 148, 411, 2016.

6. PENG D., SARAVIA F., ABBT-BRAUN G., HORN H. Occurrence and simulation of trihalomethanes in swimming pool water: A simple prediction method based on DOC and mass balance, Water Res. 88, 634, 2016.

7. MARCO E., LOURENCETTI C. GRIMALT J.O., GARI M., FERNÁNDEZ P., FONT-RIBERA L., VILLANUEVA C.M., KOGEVINAS M. Influence of physical activity in the intake of trihalomethanes in indoor swimming pools. Environ. Res. 140, 292, 2015.

8. FONT-RIBERA L., KOGEVINAS M., SCHMALZ C., ZWIENER C., MARCO E., GRIMALT J.O., LIU J., ZHANG X., MITCH W., CRITELLI R., NACCARATI A., HEEDERIK D., SPITHOVEN J., ARJONA L., DE BONT J., GRACIA-LAVEDAN E., VILLANUEVA C.M. Environmental and personal determinants of the uptake of disinfection by-products during swimming. Environ. Res. 149, 206, 2016. 
9. LOURENCETTI C., GRIMALT J.O., FERNANDEZ P., FONT-RIBERA L., VILLANUEVA C.M., KOGEVINAS M. Trihalomethanes in chlorine and bromine disinfected swimming pools: Air-water distributions and human exposure. Environ Int. 45, 59, 2012.

10. RICHARDSON S.D., DEMARINI D.M., KOGEVINAS M., FERNANDEZ P., MARCO E., LOURENCETTI C., BALLESTÉ C., HEEDERIK D., MELIEFSTE K., MCKAGUE A.B., MARCOS R., FONT-RIBERA L., GRIMALT J.O., VILLANUEVA C.M. What's in the pool? A comprehensive identification of disinfection by-products and assessment of mutagenicity of chlorinated and brominated swimming poolwater. Environ. Health Perspect. 118, 1523, 2010.

11. SILVA Z.I., REBELO M.H., SILVA M.M., ALVES A.M., CABRAL M.C., ALMEIDA A.C., AGUIAR F.R., OLIVEIRA A.L., NOGUEIRA A.C., PINHAL H.R., AGUIAR P.M., CARDOSO A.S. Trihalomethanes in Lisbon indoor swimming pools: occurrence, determining factors, and health risk classification. J. Toxicol. Environ. Health A, 75, 878, 2012.

12. FANTUZZI G., RIGHI E., PREDIERI G,, CEPPELLI G., GOBBA F., AGGAZZOTTI G. Occupational exposure to trihalomethanes in indoor swimming pools. Sci Total Environ. 264 (3), 257, 2001.

13. RIGHI E., FANTUZZI G., PREDIERI G., AGGAZZOTTI G. Bromate, chlorite, chlorate, haloacetic acids, and trihalomethanes occurrence in indoor swimming pool waters in Italy. Microchem J. 113, 23, 2014.

14. CHU H., NIEUWENHUIJSEN M.J. Distribution and determinants of trihalomethane concentrations in indoor swimming pools. Occup Environ Med. 59 (4), 243, 2002.

15. LEE J., HA K.T. ZOH K.D. Characteristics of trihalomethane (THM) production and associated health risk assessment in swimming pool waters treated with different disinfection methods. Sci Total Environ. 407, 1990, 2009.

16. PANYAKAPO M., SOONTORNCHAI S. PAOPUREE P. Cancer risk assessment from exposure to trihalomethanes in tap water and swimming pool water. J Environ Sci. 20 (3), 372, 2008

17. GOMA A., GUISASOLA A. TAYÀ C., BAEZA J.A., BAEZA M. BARTROLÍ A., LAFUENTE J., BARTROLÍ J. Benefits of carbon dioxide as $\mathrm{pH}$ reducer in chlorinated indoor swimming pools. Chemosphere. 80, 428, 2010.

18. RATAJCZAK K. Examination of the structure of the ventilation system in terms of energy efficiency for indoor swimming pools, PhD thesis, UAM, Poznań 2015 [In Polish]

19. PENTAMWA P., SUKTON B., WONGKLOM T., PENTAMWA S. Cancer risk assessment from trihalomethanes. Int J Environ Sci Dev. 4 (5), 538, 2013.

20. MISHRA B.K., GUPTA S.K., SINHA A. Human health risk analysis from disinfection by-products (DBPs) in drinking and bathing water of some Indian cities. J Environ Health Sci Eng. 12, 73, 2014.

21. VILLANUEVA C.M., FONT-RIBERA L. Health impact of disinfection by-products in swimming pools. Annali dell'Istituto Superiore di Sanità. 48(4), 387-396, 2012.

22. MAIA R., CORREIA M., BRÁS PEREIRA I.M., BELEZA V.M., MAIA R., CORREIA M., PEREIRA I.M.B., BELEZA V.M. Optimization of HS-SPME analytical conditions using factorial design for trihalomethanes determination in swimming pool water samples. MICROCHEM J. 112, 164, 2014.

23. http://www.who.int/water_sanitation_health/bathing/ srwe2chap4.pdf

24. Regulation of Minister of Health from 9 November 2015 on the requirements to be met by water in swimming pools [In Polish].

25. Guidelines for safe recreational waters, World Health Organization, Switzerland, 2006.

26. COSTET N., VILLANUEVA C.M. JAAKKOLA JJ., KOGEVINAS M., CANTOR K.P., KING W.D., LYNCH C.F., NIEUWENHUIJSEN M.J., CORDIER S. Water disinfection by-products and bladder cancer: is there a European specificity? A pooled and metaanalysis of European casecontrol studies. Occup Environ Med. 68, 379, 2011.

27. ZWIENER C., RICHARDSON S.D., DE MARINI D.M., GRUMMT T., GLAUNER T., FRIMMEL F.H. Drowning in disinfection byproducts? Assessing swimming pool water. Environ Sci Technol. 41, 363, 2007.

28. JO W.K., KWON K.D., DONG J.I., CHUNG Y. Muti-route trihalomethane exposure in households using municipal tap water treated with chlorine or ozone-chlorine. Sci Total Environ. 339, 143, 2005.

29. CAMMANN K., HUBNER K. Trihalomethane concentrations in swimmers and bath attendants blood and urine after swimming or working in indoor swimming pools. Arch Environ Health. 50 (1), 61, 1995.

30. WŁODYKA-BERGIER A., BERGIER T. The impact of water disinfection using ultraviolet on creation potential, halogen products of chlorination of the water supply network. Ochrona Środowiska. 35 (3), 53, 2013 [In Polish].

31. KLOSOK-BAZAN I., SOWA A., GONO M., GONO R. Nano-silver as a new agent for conditioning of cooling water in power stations-technical and economic aspects of technology implementation, Proceedings of the 16th International Scientific Conference on Electric Power Engineering, EPE 2015.

32. CZAJKA K., SZIWA D., LATOUR D., ADAMCZEWSKA $\mathrm{M}$. The content of trihalomethanes in brine of a therapeutic pool and in the pool hall air, Roczn. PZH 54 (1), 109, 2003 [In Polish].

33. WANG X., GARCIA L.M., ZHANG X., YANG H., XIE Y. Haloacetic acids in swimming pool and spa water in the United States and China. Front Environ Sci Eng. 8 (6), 820, 2014.

34. ERDINGER L., MASCHER F. Formation of volatile disinfection by products in swimming pool water. In proceeding of the Fourth International Swimming Pool \& Spa Conference, Research and Development on Health, Air and Water Quality Aspects of the Man-made Recreational Water Environment, March 15-18; Porto, Portugal, 2011.

35. Regulation of Minister of Health from 13 November 2015 the quality of water intended for human consumption [In Polish].

36. LUKS-BETLEJ K., BODZEK D. Occurrence of trihalomethanes, particularly those containing bromine, in Polish drinking waters. Pol J Environ Stud. 11 (3), 255, 2002. 